\title{
The influence of selected factors on the distribution of epilithic diatoms in a torrential river the Kamniška Bistrica (Slovenia)
}

\author{
Mihael J. Toman, Ana M. GrošelJ, Igor ZelniK* \\ University of Ljubljana, Biotechnical Faculty, Department of Biology, Večna pot 111, \\ SI-1000 Ljubljana
}

\begin{abstract}
Physical and chemical characteristics of habitats and species diversity in streams and rivers are strongly influenced by the catchment area. We analysed the influence of selected environmental and spatial variables on the diversity and species composition of epilithic diatom communities in periphyton. Samples were collected along the river course in a torrential river the Kamniška Bistrica. Sampling sites were selected in reaches distributed from the source to the outlet of the river and were under different influences from the catchment area and with different physical and chemical characteristics. The most common and dominant diatom species in the periphyton community were Achnanthes biasolettiana and A. minutissima. Achnanthes species often inhabit rivers and springs with moderate organic pollution. Another common diatom taxon was Gomphonema pumilum - a key species indicating oligosaprobic conditions. The results of the canonical correspondence analyses revealed that variance of the periphytic diatom community was explained by water temperature and conductivity as well as altitude. Diatom species richness was positively correlated with saprobic index values and abundance of filamentous algae in the river bed indicating a relatively low organic matter and nutrient input into the river system.
\end{abstract}

Keywords: Diatoms, periphyton, spatial distribution, torrential river

\section{Introduction}

Benthic algae and cyanobacteria are the main primary producers in torrential rivers. Benthic diatoms are frequently used for evaluating the ecological status of running waters (VIRTANEN et al. 2011), since they are various, dominant in phytobenthos, and since the ecological preferences of several species are well known (BELTRAMI et al. 2012). Habitat and species diversity of biotic communities in running waters are strongly influenced by the properties of the catchment area, land use and pollution sources.

*Corresponding author, e-mail: igor.zelnik@bf.uni-lj.si 
Diatoms colonize different aquatic habitats and substrates. They are a taxonomically diverse group with high sensitivity to chemical stressors (MARTínez DE FABRICIUS et al. 2003, Frankovich et al. 2006, Kiss et al. 2012), and vary spatially and temporally (PAssY 2007, SoININEN 2007). The relationships between diatoms and environmental variables were shown by many authors (JASPRICA and HAFNER 2005, PASSY 2007, SoInINEN 2007, LAnge et al. 2011, Jasprica et al. 2012, Virtanen and Soininen 2012, Xu et al. 2012).

Species diversity and abundance of diatoms are controlled by environmental factors like nutrients, temperature, light intensity, grazing pressure, substrate stability and discharge (IzAgirRe and Elosegi 2005). Major environmental determinants for diatom distribution in streams, as reported by SoININEN (2007) are: $\mathrm{pH}$, conductivity, total phosphorus, temperature, alkalinity, altitude, nitrates, calcium, biological oxygen demand (BOD), chlorophyll $a$ and substrate type. LANGE et al. (2011) found that light availability, nutrient concentrations and grazing pressure determined the stream diatom community composition. BeLtrami et al. (2012) stressed that altitude and geology were the main factors determining diatom communities in alpine streams. BIGGS and CLOSE (1989) suggested that disturbances such as spates reduce the effect of grazing pressure, because recolonization of invertebrates is usually slow compared to periphyton growth.

For the effective implementation of the European Water Framework Directive (WFD) the member states are supposed to provide the unimpacted reference state of the system (Kelly et al. 2012, VÁrbíró et al. 2012). The potential of diatoms as bioindicators for the assessment of water quality and reference conditions is well known (AlmEIDA and FeIO 2012)

Samples were collected along the river's course in different seasons. Hydrological conditions in the Kamniška Bistrica are well known; several times per year the flow increases 10-20 fold compared to the basal flow. Studies dealing with the relationship between environmental variables and algal communities in Slovenia have been performed only in extreme environments (KRIVOGRAd KLEMENČIČ et al. 2010, KRIVOGRAd KLEMENČIČ and Toman 2010), while the distribution of diatoms along the gradients in running waters is poorly known. Also, no seasonal studies of environmental and spatial effects on diatom communities in this river or other similar rivers in the region have been completed, and therefore no comparisons with previous studies were possible.

The main goal of this research was to investigate the influence of selected environmental, spatial and temporal factors on the species composition and diversity of epilithic diatom assemblages to investigate their use as indicators in torrential rivers.

\section{Materials and methods}

\section{Study area}

The Kamniška Bistrica River is a left tributary of the Sava River and an important part of the Danube catchment area, collecting water from the southern belt of the limestone Alps. The length of the river is $32.8 \mathrm{~km}$, drainage area $546.1 \mathrm{~km}^{2}$ and the average (annual) discharge is about $7 \mathrm{~m}^{3} \mathrm{~s}^{-1}$. The karstic source $\left(46^{\circ} 19^{\prime} 35.83^{\prime \prime} \mathrm{N}, 14^{\circ} 35^{\prime} 15.45^{\prime \prime} \mathrm{E}\right)$ is at an altitude of $600 \mathrm{~m}$ a.s.l. The riverbed mainly consists of limestone and magnesium limestone (dolomite) of Middle to Early Jurassic age (BUSER 2009). The catchment area is characterized by dispersed settlements, agricultural land, farms and different kinds of industry, all of which are potential sources of inorganic and organic compounds (Tab. 1). 
Tab. 1. Sampling sites on the Kamniška Bistrica river and some of their characteristics; $\mathrm{L}$ - left, $\mathrm{R}$ - right.

\begin{tabular}{|c|c|c|c|c|c|}
\hline Site & Coordinates & $\begin{array}{l}\text { Altitude } \\
\text { (m) }\end{array}$ & $\begin{array}{c}\text { Distance from } \\
\text { source }(\mathrm{km})\end{array}$ & $\begin{array}{c}\text { Channel } \\
\text { width }(\mathrm{m})\end{array}$ & Description and land-use \\
\hline K1 & $\begin{array}{l}46^{\circ} 19^{\prime} 35.8^{\prime \prime N} \\
14^{\circ} 35^{\prime} 15.5^{\prime \prime} \mathrm{E}\end{array}$ & 582 & 0.8 & 5.3 & $\begin{array}{l}\text { L-bank: forest; R-bank: forest, dry } \\
\text { channel, grassland and pastures, } \\
\text { parking area with cottage and } \\
\text { restaurant. }\end{array}$ \\
\hline K2 & $\begin{array}{l}46^{\circ} 16^{\prime} 57.0^{\prime \prime N} \\
14^{\circ} 36^{\prime} 54.5^{\prime \prime} \mathrm{E}\end{array}$ & 477 & 4.7 & 11.0 & $\begin{array}{l}\text { L-bank: meadow, vegetable-garden, } \\
\text { road and parking place, restaurant, } \\
\text { forest; R-bank: forest. }\end{array}$ \\
\hline K3 & $\begin{array}{l}46^{\circ} 14^{\prime} 47.4^{\prime \prime} \mathrm{N} \\
14^{\circ} 36^{\prime} 08.2^{\prime \prime} \mathrm{E}\end{array}$ & 402 & 9.1 & 14.7 & $\begin{array}{l}\text { L-bank: floodplain wood; R-bank: } \\
\text { floodplain wood, meadows, road, } \\
\text { downstream settlements, factory, } \\
\text { quarry. }\end{array}$ \\
\hline K4 & $\begin{array}{l}46^{\circ} 07^{\prime} 37.6^{\prime \prime} \mathrm{N} \\
14^{\circ} 36^{\prime} 25.3^{\prime \prime} \mathrm{E}\end{array}$ & 289 & 24.8 & 22.1 & $\begin{array}{l}\text { Regulated channel; remnants of } \\
\text { lowland oak-hornbeam forest, } \\
\text { riparian zone with clearings } \\
\text { overgrown with invasive alien } \\
\text { plant species, settlements. }\end{array}$ \\
\hline K5 & $\begin{array}{l}46^{\circ} 05^{\prime} 18.9^{\prime \prime} \mathrm{N} \\
14^{\circ} 37^{\prime} 34.3^{\prime \prime} \mathrm{E}\end{array}$ & 269 & 30.9 & 22.7 & $\begin{array}{l}\text { Regulated channel; degraded banks, } \\
\text { overgrown with invasive alien plants } \\
\text { and pioneer shrubs and trees; } \\
\text { improved grassland, settlement, } \\
\text { remnants of lowland oak-hornbeam } \\
\text { forest. }\end{array}$ \\
\hline
\end{tabular}

\section{Sampling and laboratory analyses}

Samples were taken at five sampling sites (Tab. 1) in March, July and August. The sample from the beginning of March is considered a winter sample due to the very low temperatures. The sample from the beginning of July represents a transition between spring and summer, since there was a longer period of rainy and relatively cold weather and elevated discharge as well. The sample from the end of August is a typical summer sample. Epilithic diatoms in the periphyton communities were sampled from stones $(\varphi=6-20 \mathrm{~cm})$ at each site, by scraping and brushing off the stone surface $\left(5 \mathrm{~cm}^{2}\right.$ per stone). Samples for diatom identification were preserved in $4 \%$ formaldehyde, samples for chlorophyll $a$ analyses were stored at $4{ }^{\circ} \mathrm{C}$. For taxonomic identification all samples were diluted to $50 \mathrm{~mL}$, homogenized with a magnetic stirrer and subsamples were treated with concentrated nitric acid $\left(\mathrm{HNO}_{3}\right)$. Permanent slides of diatom frustules were prepared using the high refraction mountant Naphrax ${ }^{\circledR}$. Diatom taxa were identified and counted using an Olympus CX41 microscope with an oil-immersion objective at a magnification of $1000 \times$, taxonomy followed Kramer and Lange-Bertalot (1991). The proportion of diatoms, Cyanobacteria and other algae were analysed at a magnification of $400 \times$. Cyanobacteria and other non-diatom algae were identified using Hindék et al. (1978), Biggs and Kilroy (2000), KomÁreK and AnAgnostidis (2002). Proportions of diatom taxa among all algae were obtained by further division of their total share according to the proportions of counted frustules at a magnification of $1000 \times$. 
At each sampling site selected physical and chemical parameters were measured (water depth, current velocity, $\mathrm{pH}, \mathrm{O}_{2}$ concentration, $\mathrm{O}_{2}$ saturation, temperature and conductivity), using the portable multi-meter PCD 650 (Eutech Instruments, Singapore). Light intensity was measured with the point sensor LI-1000 (LI-COR). The cover of inorganic and organic substrate was estimated according to the AQEm (2002) protocol (Tab. 2). Shading was calculated as the ratio between the height and density of riparian vegetation and the width of the channel.

Tab. 2. The structure of organic and inorganic substrates at the sampling sites (K1-K5). Mean coverage $(\%)$ of each fraction of the substrate; $\mathrm{CPOM}$ - coarse particulate organic matter, FPOM - fine particulate organic matter.

\begin{tabular}{lrrrrr}
\hline Type of substrate & K1 & K2 & K3 & K4 & K5 \\
\hline Filamentous algae & 12 & 3 & 3 & 20 & 22 \\
Mosses & 17 & 5 & 4 & 4 & 5 \\
Terrestrial plants & 3 & 3 & 3 & 3 & 3 \\
Xylal & 4 & 3 & 5 & 7 & 4 \\
CPOM & 3 & 3 & 3 & 3 & 3 \\
FPOM & 0 & 0 & 3 & 3 & 3 \\
\hline Megalithal & 50 & 35 & 3 & 3 & 3 \\
Macrolithal & 20 & 45 & 25 & 30 & 25 \\
Mesolithal & 10 & 15 & 45 & 50 & 45 \\
Microlithal & 5 & 5 & 10 & 10 & 15 \\
Akal & 15 & 0 & 5 & 3 & 5 \\
Psammal & 0 & 0 & 3 & 0 & 5 \\
Argyllal & 0 & 0 & 0 & 0 & 3 \\
\hline
\end{tabular}

Water samples were analyzed in the laboratory. Water transparency and the chlorophyll $a$ content were measured spectrophotometrically. Concentration of nitrates were measured with the Na-salicylate method (MONTEIRO et al. 2003), while the soluble reactive phosphorus (SRP) was measured using the $\mathrm{SnCl}_{2}$ method (ApHA 1998). Periphyton biomass was also determined as dry weight (at $105^{\circ} \mathrm{C}$ ) of the biofilm covering the sampled stones scratched from the $5 \mathrm{~cm}^{2}$ rectangle. Results of these measurements are given in table 3 .

\section{Data analyses}

Relative abundance (percentage values) of the diatom taxa were calculated for each sample (Tab. 4) and used in further analyses. The Shannon-Wiener (S-W) diversity index was used to estimate diatom diversity and the saprobic index (SI) was calculated using saprobic $\left(\mathrm{s}_{\mathrm{i}}\right)$ and indicator values $\left(\mathrm{G}_{\mathrm{i}}\right)$ according to Kosi et al. (2006) to determine water quality using the following formula:

$$
\mathrm{SI}=\frac{\sum_{i=1}^{n}\left(\mathrm{~h}_{\mathrm{i}} \times \mathrm{G}_{\mathrm{i}} \times \mathrm{s}_{\mathrm{i}}\right)}{\sum_{i=1}^{n}\left(\mathrm{~h}_{\mathrm{i}} \times \mathrm{G}_{\mathrm{i}}\right)}
$$

$\left(\mathrm{h}_{\mathrm{i}}\right.$ - abundance of the taxon $\mathrm{i} ; \mathrm{n}$ - number of taxa) 


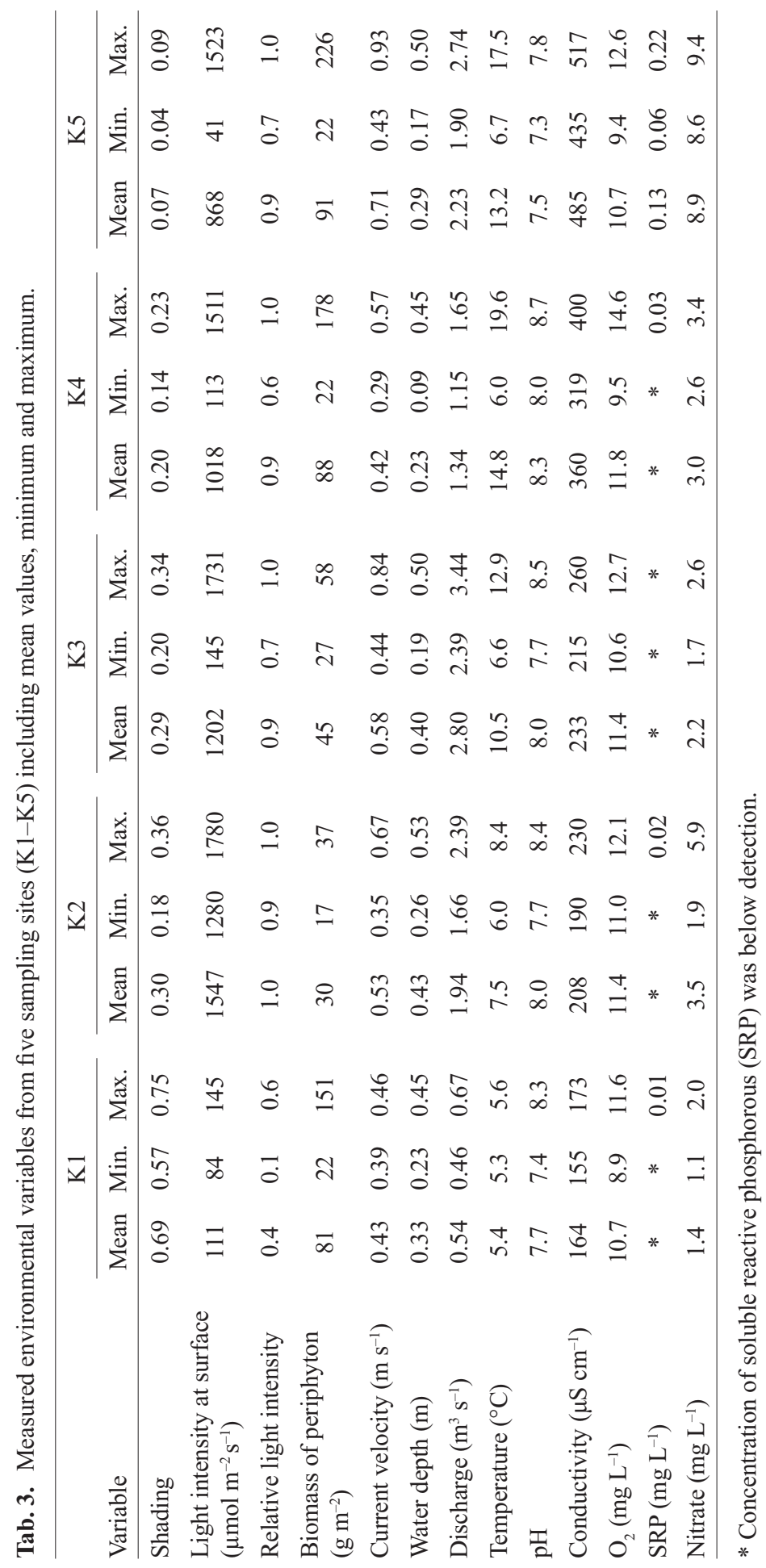




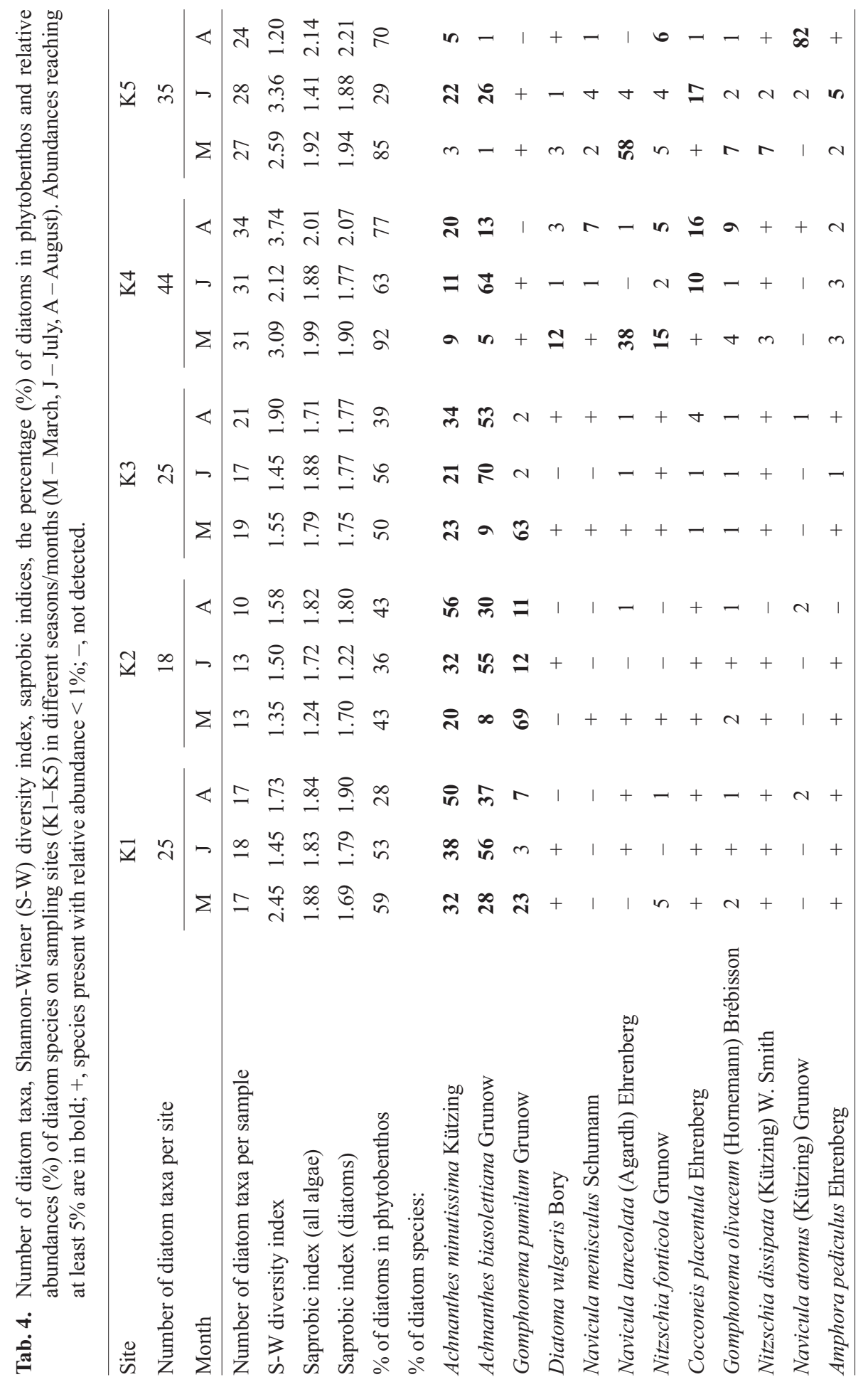


The cluster analyses were performed with the program Syn-Tax (PoDANi 2001) to establish the similarity between diatom communities from different sampling sites/seasons. As a method of linkage, unweighted pair group method with arithmetic mean (UPGMA) was used and the Bray-Curtis index served as a similarity measure for the creation of a dendrogram.

Detrended correspondence analysis (DCA) was applied to the diatom percentage data to explore the patterns of species changes and biological species turnover (the gradient length). The eigenvalue for the first DCA axis was $>0.4(0.76)$, while gradient length was 3.54 SD (standard deviation units of species turnover) and indicated strong unimodality (TER BRAAK and Verdonschot 1995) and therefore canonical correspondence analysis (CCA) was chosen to explore the relationships between diatom assemblages and explanatory variables.

Separate CCAs for each environmental variable were performed to test the significance of its influence on the variation of species composition. Variables were gathered in three groups representing spatial, temporal and environmental gradients. Forward selection of explanatory variables was used to provide a ranking of the relative importance of the specific variables and to avoid co-linearity. Unrestricted Monte Carlo test with 999 permutations was used to test the statistical significance of the variables and canonical axes. Another CCA was done with a subset of only significant variables $(p<0.05)$ and the proportions of variance explained by these variables were calculated. Variance partitioning by the mentioned groups of variables and specific significant variables was performed with a series of pCCAs. Some of the variables were not normally distributed so the data were log-transformed. Ordination of the samples according to the most important environmental parameters was made using CCA. The whole set of analyses was performed using CANOCO 4.5 (TER BRAAK and ŠMiLAUER 2002).

Relationships between the diatom diversity and environmental factors were explored with Spearman correlation coefficients in SPSS version 17.

\section{Results}

\section{Distribution and diversity of diatoms}

A total of 52 diatom taxa were identified in the samples from the Kamniška Bistrica River. The majority of these taxa (44) were found at the sampling site K4, in the regulated channel. The highest number of diatom species (40) was found in summer samples (A), and the lowest (34) in winter (M) samples. Two species occurred with a high share in all seasons, namely Achnanthes biasolettiana (5-64\%) and A. minutissima (9-21\%). The similarity of diatom assemblages is presented in Fig. 1, which indicates that about one third of taxa were common to all samples (Tab. 4). The dendrogram shows that two larger clusters are formed according to locations/spatial factors. The left group uniting the upper three locations (K1, $\mathrm{K} 2, \mathrm{~K} 3$ ) shows a higher sample similarity than downstream locations (K4, K5). The total number of diatom taxa at the source site (K1) was 25 (Tab. 4). The most abundant species ( $\geq 5 \%$ ) were Achnanthes biasolettiana, A. minutissima and Gomphonema pumilum.

The lowest number of diatom taxa (18 species) was detected downstream at the site K2 (Tab. 4). The most abundant were the co-dominant taxa Gomphonema pumilum, Achnanthes minutissima and A. biasolettiana with shares between $96 \%$ and $99 \%$. 


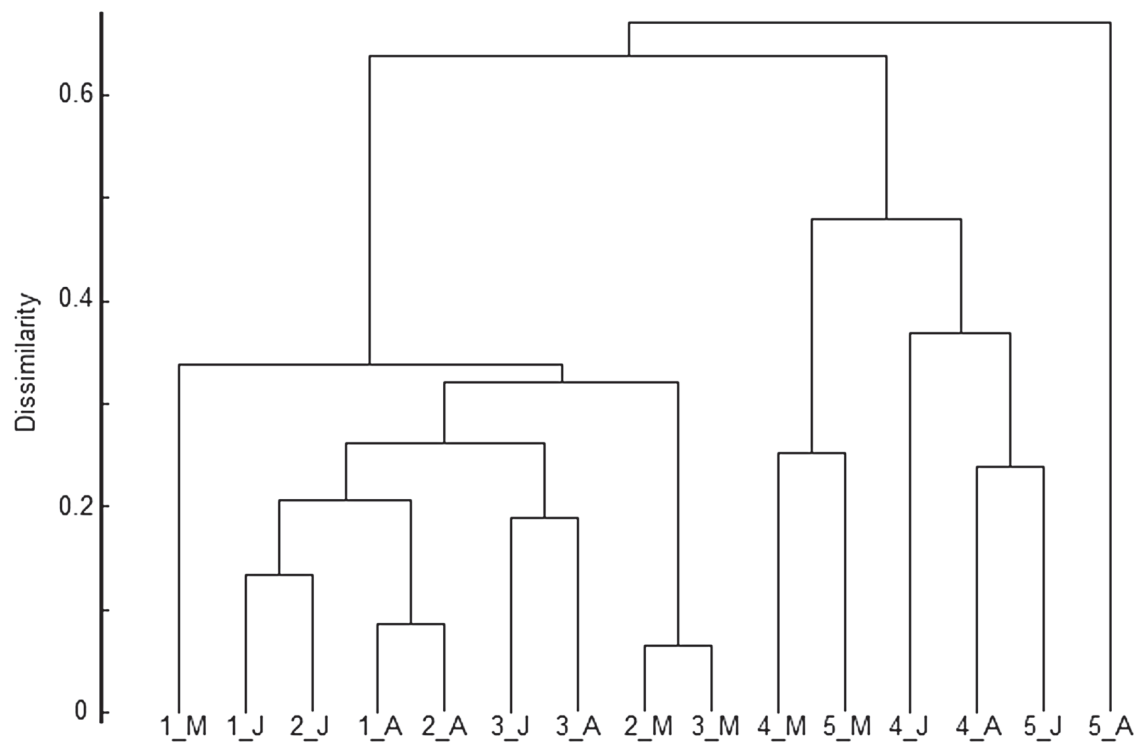

Fig. 1. Dendrogram showing the similarity of diatom communities in different sampling sites (K1K5) in different seasons/months (M - March, J - July, A - August). Left cluster unites the following samples: 1_M and 1_J (K1 from March and July), 2_J (K2 from July), 1_A and 2_A (K1 and K2, both from August), 3_J and 3_A (K3 from July and August), 2_M and 3_M (K2 and K3, both from March). Cluster on the right side includes the samples: 4_M and 5_M (K4 and K5, both from March), 4_J and 4_A (K4 from July and August), 5_J and 5_A (K5 from July and August).

The total number of diatom taxa at site K3 was 25 (Tab. 4), with the same co-dominant species as in site K2 (Gomphonema pumilum, Achnanthes biasolettiana and A. minutissima).

The site in the regulated channel (K4) exhibited the most species-rich diatom assemblage with 44 taxa (Tab. 4). Eight taxa reached $\geq 5 \%$ of the relative abundance, two species (Achnanthes biasolettiana and A. minutissima) occurred with a high share in all seasons. Other common species included: Cocconeis placentula (A and J), Diatoma vulgaris, Navicula lanceolata (M), Gomphonema olivaceum and Nitzschia fonticola. In the August sample the highest number of taxa were observed (34) and the highest S-W diversity index value (3.74) was calculated (Tab. 4) - the sample also contained the highest number of taxa (6) with a relative abundance $\geq 5 \%$ (Achnanthes minutissima, Cocconeis placentula, A. biasolettiana, etc).

The total number of diatom taxa downstream of the regulated channel at site $\mathrm{K} 5$ was 35 (Tab. 4). The S-W diversity index value was low (1.2) due to the dominance of the species Navicula atomus (82\%). Eight other taxa occurred with a relative abundance $\geq 5 \%$ : Navicula lanceolata, Achnanthes biasolettiana, A. minutissima, Cocconeis placentula, Nitzschia dissipata, N. fonticola, Gomphonema olivaceum and Amphora pediculus. 


\section{Saprobic index and water quality}

The average SI value for all sampling sites was 1.81 which indicates a $2^{\text {nd }}$ quality class or $\beta$-mesosaprobic level with moderate organic loading. That was also the most common quality class in our survey. Samples from the sites close to the source were classified into $1^{\text {st }}$ or $2^{\text {nd }}$ class which is the oligo- to $\beta$-mesosaprobic class (Tab. 4).

\section{Influence of environmental and spatial factors on diatom species composition}

The greatest share of variance of the diatom community was explained by water conductivity $(30.3 \%)$, water temperature $(14.2 \%)$ and altitude $(12.3 \%)$. Variance partitioning revealed (Tab. 5) that the highest share of diatom species composition variation is influenced by environmental factors $(25 \%)$, namely water temperature and conductivity, followed by altitude $(8.5 \%)$, which is the only spatial factor with significant influence. Water conductivity and altitude are gradients that correlate with the $1^{\text {st }}$ axis of the CCA (Fig. 2A, Tab. 6), while water temperature correlates with the $2^{\text {nd }}$ axis of the CCA.

Tab. 5. Results of forward selection calculated with canonical correspondence analysis (CCA), 999 permutations. Significant environmental variables $(\mathrm{p}<0.05)$ and the percentage of the total variance of species data explained (\%TVE) - gross effect of the variable and percentage as a result of variance partitioning when pCCAs were performed - net effect of the variable.

\begin{tabular}{llcccccc}
\hline \multirow{2}{*}{ Variable } & & \multicolumn{2}{c}{ Gross effect } & & \multicolumn{2}{c}{ Net effect } \\
\cline { 3 - 4 } \cline { 6 - 7 } & & $\mathrm{p}$ & $\mathbf{\%}$ TVE & & $\mathrm{p}$ & \% TVE \\
\hline Conductivity & Environmental & & 0.001 & $\mathbf{3 0 . 3}$ & & 0.013 & $\mathbf{1 1 . 4}$ \\
Temperature & Environmental & 0.004 & $\mathbf{1 4 . 2}$ & & 0.006 & $\mathbf{1 4 . 2}$ \\
Altitude & Spatial & 0.006 & $\mathbf{1 2 . 3}$ & & 0.040 & $\mathbf{8 . 5}$ \\
\hline
\end{tabular}

Tab. 6. The results of canonical correspondence analysis, showing the eigenvalues and percentage of the explained variance of diatom assemblages for the first two axes and their correlations with significant environmental variables. Total inertia was 1.055 and sum of all canonical eigenvalues was 0.596 .

\begin{tabular}{lcc}
\hline & Axis 1 & Axis 2 \\
\hline Eigenvalue & 0.325 & 0.161 \\
Explained variance of species-environment relation $(\%)$ & 54.5 & 27 \\
Correlation with variables: & & \\
Conductivity & -0.9156 & -0.1322 \\
Temperature & -0.3359 & -0.7993 \\
Altitude & 0.8918 & 0.2143 \\
\hline
\end{tabular}

Diatoms presented on the left side of Fig. 2B are found in the downstream sites K4 and K5 (Fig. 2A) and prefer water with high content of electrolytes (conductivity), while diatoms in the sites closer to the source, which are found on the right side, prefer water with lower conductivity. 

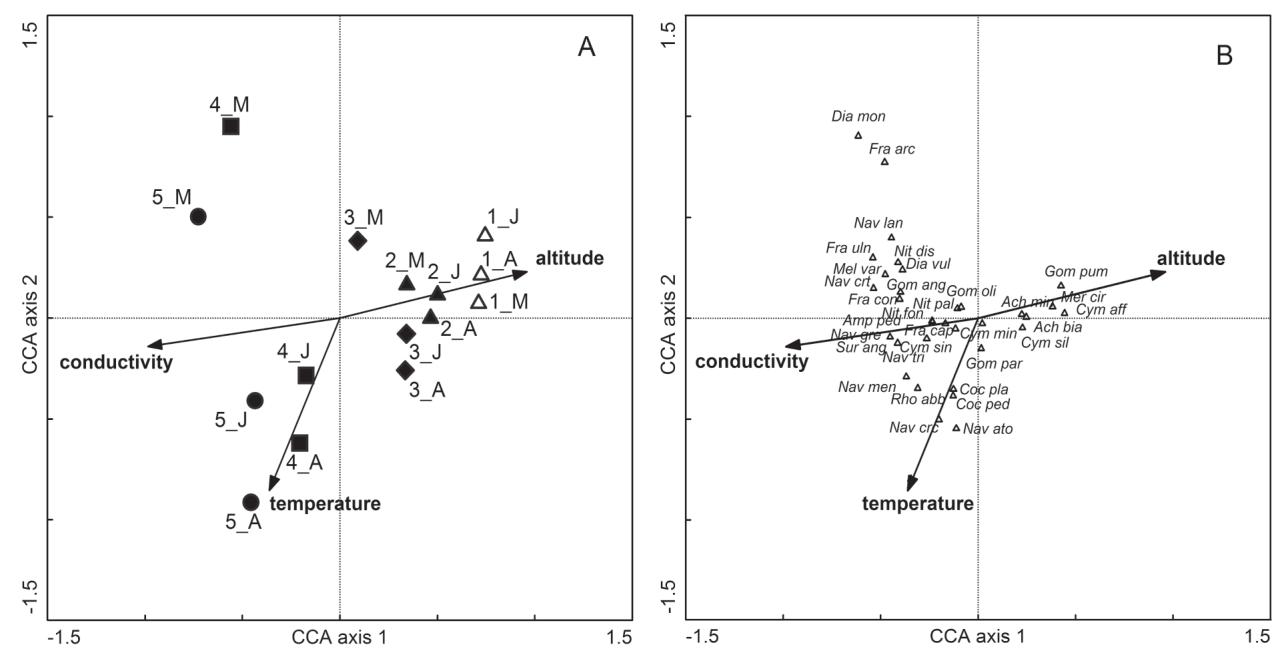

Fig. 2. Canonical correspondence analysis ordination diagrams of diatom assemblages from various seasons and sites of the Kamniška Bistrica River. Only significant variables are included. (A) distribution of the samples along the environmental variables, where sites are represented with numbers (1-5) and seasons/months with letters (M - March, J - July, A - August); (B) distribution of diatom species present in at least three samples are shown: Ach bia-Achnanthes biasolettiana, Ach min - Achnanthes minutissima, Amp ped-Amphora pediculus, Coc ped-Cocconeis pediculus, Coc pla-Cocconeis placentula, Cym aff-Cymbella affinis, Cym min-Cymbella minuta, Cym sil-Cymbella silesiaca, Cym sin-Cymbella sinuata, Dia mon - Diatoma moniliformis, Dia vul - Diatoma vulgaris, Fra arc - Fragilaria arcus, Fra cap - Fragilaria capucina, Fra con-Fragilaria construens, Fra uln-Fragilaria ulna, Gom ang - Gomphonema angustatum, Gom oli-Gomphonema olivaceum, Gom par - Gomphonema parvulum, Gom pum - Gomphonema pumilum, Mel var - Melosira varians, Mer cir Meridion circulare, Nav ato - Navicula atomus, Nav crt - Navicula cryptotenella, Nav greNavicula gregaria, Nav lan - Navicula lanceolata, Nav men - Navicula menisculus, Nav tri - Navicula tripunctata, Nit dis - Nitzschia dissipata, Nit fon - Nitzschia fonticola, Nit pal Nitzschia palea.

\section{Correlation between environmental factors and diatom community diversity}

Correlations between environmental, spatial (altitude, distance from source, channel width) and temporal (seasons) factors were calculated. A correlation of very high significance was calculated between altitude and distance from source. Conductivity was significantly correlated with concentrations of nitrate, SRP and distance from source. Temperature was negatively correlated with altitude and content of $\mathrm{O}_{2}$, but positively with distance from source and with relative light intensity.

Diatom species richness was positively correlated $(\mathrm{p}<0.05)$ with the saprobic index calculated on the basis of diatoms and other algae, with the cover value of organic substrate (filamentous algae and xylal) and quality class (Tab. 7). On the other hand, diversity of diatoms was negatively correlated $(\mathrm{p}<0.05)$ with the share of macrolithal, average water depth and light intensity. The most significant correlations are presented in Figs. 3A-E. 
Tab. 7. Summary of regression analyses between diatom species richness (Nr. of taxa) and ShannonWiener diversity index $\left(\mathrm{H}^{\prime}\right)$ and some of the environmental parametres; $* * \mathrm{p}<0.01,{ }^{*} \mathrm{p}<$ 0.05 .

\begin{tabular}{lcc}
\hline Parameter & H' & Nr. of taxa \\
\hline Water quality class & 0.508 & $0.596^{*}$ \\
Saprobic index (all algae) & 0.217 & $0.788^{* *}$ \\
Saprobic index (diatoms) & 0.307 & $0.627^{*}$ \\
Algae & 0.437 & $0.800^{* *}$ \\
Xylal & 0.127 & $0.565^{*}$ \\
Macrolithal & -0.278 & $-0.662^{* *}$ \\
Water depth & -0.213 & $-0.763^{* *}$ \\
Light intensity & -0.243 & $-0.588^{*}$ \\
\hline
\end{tabular}
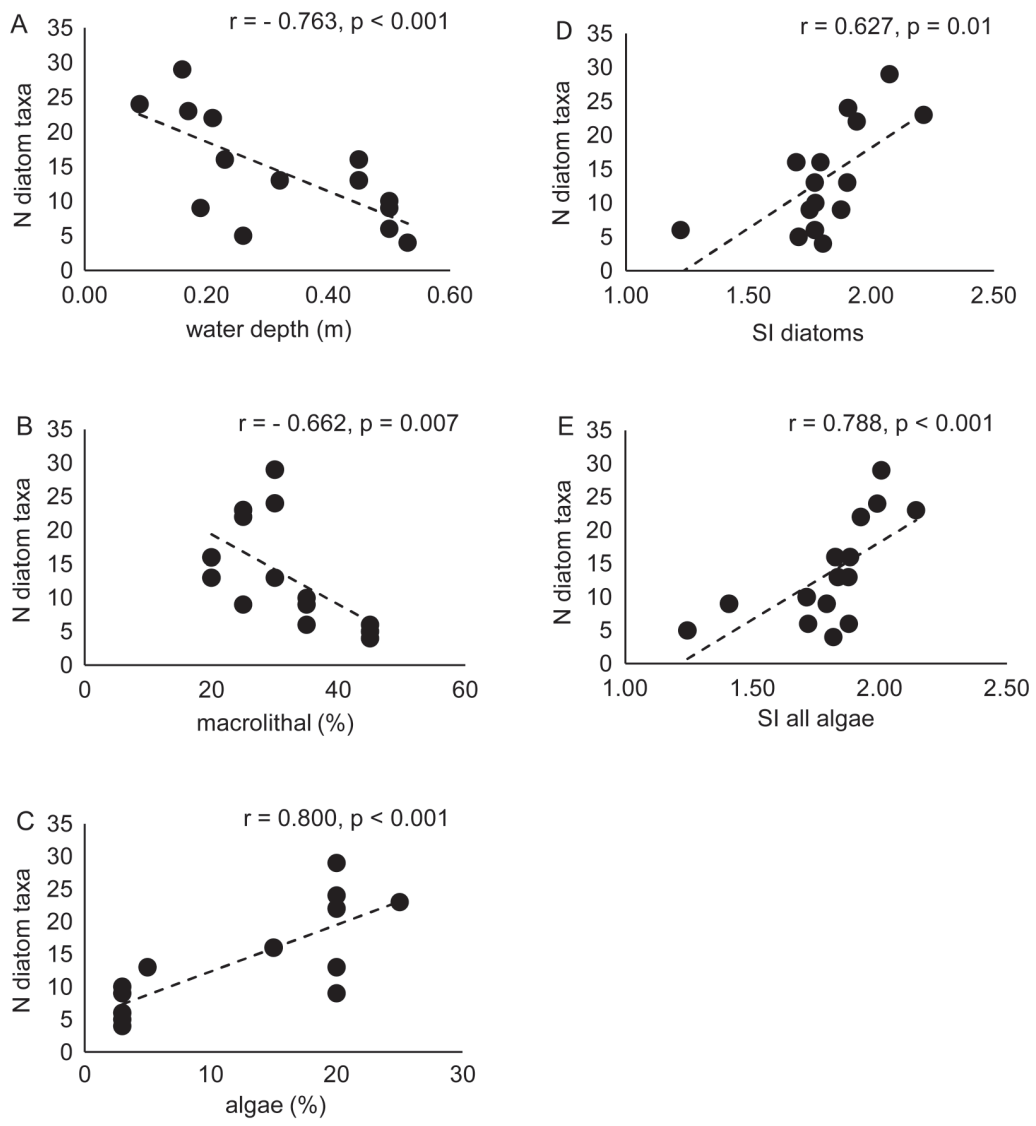

Fig. 3. Statistically significant correlations between the number $(\mathrm{N})$ of diatom taxa in the sample and water depth (A), \% of macrolithal in the substrate (B), $\%$ of cover with filamentous algae (C), saprobic index (SI) calculated on the base of diatoms (D) and SI calculated on the base of all algae (E). 


\section{Discussion}

In the temperate zone, diatoms are the most abundant algae in the periphyton community, especially in streams with a stony substrate, with the highest share in spring and autumn periods. In the samples from the investigated torrential river, diatoms represented from 28 to $92 \%$ of the primary producers (Tab. 4). The highest number of the species was found in August - when low abundances of Chlorophyta and Cyanobacteria were detected.

The similarity of diatom assemblages (Fig. 1) reflected the locations / spatial factors. The left group uniting the upper three locations shows a higher sample similarity than downstream locations. A lower rate of similarity is a consequence of greater variation in natural factors such as water temperature, as well as the variety of human impacts on the river ecosystem. About a third of taxa were common to all samples (see Tab. 4). For instance, species Achnanthes minutissima, A. biasolettiana, Gomphonema pumilum, G. olivaceum and Cocconeis placentula were most common and present in all samples; moreover, they often reached high shares in the epilithic community (Tab. 4). These taxa have the ability to attach firmly to substrata, which increases the temporal occurrence of these diatoms (VIRTANEN et al. 2011). Authors from different parts of the world report that A. minutissima is one of the most frequent taxa in epilithic diatom communities in running waters (HoffMAN et al. 2011, SoltanPour-GARGARI et al. 2011, VirTANEN et al. 2011), mainly because of the wide ecological amplitude, making it a pioneer taxon.

According to Hofrman et al. (2011) Achnanthes biasolettiana and Gomphonema pumilum prefer Ca-rich, oligotrophic to mesotrophic running waters on limestone bedrock of the alpine and pre-alpine regions where they often reach high abundance. This is also the case in our research area and in accordance with our results (Tab. 4). Besides, Hoffman et al. (2011) and VIRTANEN et al. (2011) emphasize that A. minutissima and G. pumilum inhabit periphyton communities as a complex of different species (HoffMAN et al. 2011) so the same species is not necessarily present in all samples. These facts explain their common occurrence and relatively wide ecological niches.

The most abundant winter diatoms with relative abundance $\geq 5 \%$ in the winter period, beside the common taxa (Achnanthes biasolettiana, A. minutissima, Gomphonema pumilum) were: Navicula lanceolata, Diatoma vulgaris, Gomphonema olivaceum, Nitzschia fonticola, and Nitzschia dissipata.

The taxa Achnanthes biasolettiana and A. minutissima were also the most abundant in spring and summer. Their ability to firmly attach to the substratum in changeable water flows (VIRTANEN et al. 2011) as well as their quick recolonization could be the reasons for their constant presence in the periphyton community. Some other species that attach to substrata, such as Cocconeis placentula and Gomphonema pumilum also exceeded the share of $5 \%$ in that period. The mentioned situation in August was similar in the first three sites, while in the downstream section the most common species were A. minutissima, Cocconeis placentula, Navicula atomus and Nitzschia fonticola.

The most diverse genus was Navicula with 14 species found, which was in accordance with findings in SoltanPour-Gargari et al. (2011) who reported Navicula and Nitzschia to be the most diverse genera.

Samples from the upper three sites (source region) showed low values (1.35-2.5) of the $\mathrm{S}-\mathrm{W}$ index as a result of lower species richness and species dominance (Tab. 4). Low concentrations of nitrates, SRP and total dissolved solids in the water, as well as low tempera- 
tures and unstable substrate could be the main ecological factors for very low productivity, which causes low species richness and/or diversity. A relatively low value of the diversity index (1.20) was calculated from summer samples at the downstream site (K5) due to the dominance of the species Navicula atomus (82\%). This species occurrs frequently in warmer periods and is very tolerant of organic loading (HürLimann and Schanz 1993, Goma 2005). The facts that in August temperature reached the highest values and site K5 lies downstream of the water treatment plant, the farming and urban area might explain the dominance of the mentioned species, which reduced the diversity of diatom community.

The greatest diversity index value (3.74) was calculated for the summer downstream sample K4, where nutrient concentrations were high. This sample was the most species-rich and had the highest number of taxa (6) exceeding a relative abundance of 5\%, i.e., Achnanthes minutissima, Cocconeis placentula and A. biasolettiana, together comprising about $50 \%$ of the diatom assemblage. However, no significant correlations between ShannonWiener diversity index and any of the included variables was calculated.

Water quality was evaluated using the saprobic index. Most of the sites belong to oligosaprobic and oligo- $\beta$-mesosaprobic states, characteristic of moderate organic loading. The most abundant taxa at sites $\mathrm{K} 2, \mathrm{~K} 1$ and $\mathrm{K} 3$ (such as Achnanthes minutissima and A. biasolettiana) were characteristic of a $\beta$-mesosaprobic state, while Gomphonema pumilum is characteristic of an oligosaprobic state (HoFFMAN et al. 2011).

Samples from the sites close to the source were classified into $1^{\text {st }}$ or $2^{\text {nd }}$ class which is the oligo- to $\beta$-mesosaprobic class (Tab. 4) and indicates low organic loading.

Influences of environmental and spatial factors on the diatom community were tested using CCA. The significant variables explained almost $57 \%$ of diatom species composition (Tab. 5), which is similar to results published by PASSY (2007), where the share reached $60 \%$. On the other hand, there is a great difference in results of variance partitioning, since the share of variance explained with pure environmental factors in our case $(25.6 \%)$ was almost three times higher than calculated by PASsY (2007) (9\%), while in case of the spatial factors our result was about twice as low. A possible reason for mentioned differences could be the size of research area, since the river we studied was four times as short as the river studied by PASSY (2007); SoININEN (2007) reports that the relative importance of environmental and spatial factors varies with study scale. Moreover, SoININEN (2007) claims that distance effects are negligible over small scales, while at broader scales they may overwhelm the importance of local environmental factors.

In our study, the highest share of variance of the epilithic diatom community was explained by water conductivity and temperature (environmental factors) and altitude (topographic factor). Their pure (net) effects on diatom species composition were slightly different (Tab. 5), as water temperature explained the highest share of the variance. Temperature, conductivity and altitude were also found to be major determinants of diatom communities by SoININEN (2007), temperature was emphasised by IZAGIRRE and Elosegi (2005), altitude by Beltrami et al. (2012) and conductivity by VirTANen and SoININEN (2012).

The share of total variance explained with pure selected factors dropped to $34 \%$, most probably due to the high correlation of conductivity with altitude. The spatial variation in communities may also reflect the effects of unmeasured environmental variables (VIRTANEN and SoININEN 2012). Considering the net effects of variables the highest share of variance is explained by temperature, which highly correlates with relative light intensity, while no significance was calculated with seasons. 
Diatoms distributed on the left side of the diagram (Fig. 2B) are found in the downstream sites K4 and K5 (Fig. 2A) and prefer water with high content of electrolytes (conductivity). Species like Navicula cryptotenella, N. gregaria, N. veneta, Nitzschia palea, Surirella angusta have been defined as indicators for eutrophic and polluted streams and found in streams with high conductivity and phosphorous and nitrogen content (VIRTANEN AND SoININEN 2012).

Exogenous factors that influence the periphytic community often have synergistic effects making the influence of a single variable on the species composition, diversity and other community characteristics hard to define. There is also the question of size of the studied area (SoININEN 2007), which determines the order of specific factors. Furthermore, there is also the influence of biotic interactions (grazing, competition) which are exceedingly difficult to quantify. The mentioned facts could be possible reasons for the differing conclusions on the importance of various factors in structuring epilithic diatom communities (Soininen 2007, LANGe et al. 2011, Beltrami et al. 2012).

A highly significant correlation was calculated between altitude and distance from source indicating that these spatial variables are very closely related. Conductivity is significantly correlated with concentrations of nitrate, SRP and distance from source, which also represent increased human influence (Tab. 1). On the other hand conductivity also correlates with cover of filamentous algae and periphyton biomass as dependant elements, indicating that conductivity could suitably reflect trophic conditions, which is very simple to measure. As expected, temperature was negatively correlated with altitude and content of $\mathrm{O}_{2}$, but positively with distance from source. The highest correlation was calculated with relative light intensity, which is also an important factor determining the structure and function of the periphyton community (LANGE et al. 2011).

Species diversity is determined by the diversity of microhabitats and effects like amount of nutrients, water temperature, flow regime and stability of the ecosystem, which depends mainly on hydrological disturbances and pollution (Moss 2010). VelgHE et al. (2012) calculated negative correlation between diatom species richness and amount of phosphorous. In our case diatom species richness was unexpectedly positively correlated $(\mathrm{p}<0.05)$ with the saprobic index calculated on the basis of diatoms / all algae, with water quality class and with the cover value of filamentous algae (Tab. 7, Fig. 3). These findings indicate low content of organic matter and nutrients, too low even to enable the thriving of species-rich epilithic diatom community, which needs higher amounts of nutrients and/or organic matter to support high number of species.

\section{Conclusion}

Our results revealed considerable changes in diatom species composition along the river, which much outweighed the changes during the year. Other researchers observed minor changes in diatom community composition between seasons.

The highest share of variance of the periphytic diatom community was explained by environmental factors - by water temperature and conductivity. Considering that temperature mostly depends on climatic conditions, the conductivity is greatly influenced by human impact, for instance it strongly correlates with nitrates and SRP. Besides, it also strongly correlated with periphyton biomass and cover of filamentous algae, so it seems to be a good indicator of nutrient loading. 
Water Framework Directive as the official monitoring system in the European Union is more focused on the evaluation of ecosystem state, rather than water quality state. Diatom communities are good indicators of an ecological state and should be used further in monitoring.

\section{Acknowledgements}

We would like to thank Gorazd Kosi, PhD. for his help with diatom determination.

\section{References}

Almeida, S. F. P., Feio, M. J., 2012: DIATMOD: diatom predictive model for quality assessment of Portuguese running waters. Hydrobiologia 695, 185-197.

ApHa (American Public Health Association), 1998: Standard methods for examination of water and waste water. American Public Health Association, Washington, DC.

AQEM consortium, 2002: Manual for the application of the AQEM method: a comprehensive method to assess European streams using benthic macroinvertebrates, developed for the purpose of the Water Framework Directive. Version 1.0, February 2002.

Beltrami, M. E., Ciutti, F., Cappelletti, C., Lösch, B., Alber, R., Ector, L., 2012: Diatoms from Alto Adige/Südtirol (Northern Italy): characterization of assemblages and their application for biological quality assessment in the context of the Water Framework Directive. Hydrobiologia 695, 153-170.

Biggs, B. J. F., Close M. E., 1989: Periphyton biomass dynamics in gravel bed rivers - the relative effects of flows and nutrients. Freshwater Biology 22, 209-231.

Biggs, B. J. F., Kilroy, C., 2000: Stream periphyton monitoring manual. NIWA, The New Zealand Ministry for the Environment, Christchurch.

BusER, S., 2009: Geological map of Slovenia. Geological survey of Slovenia, Ljubljana.

Frankovich, F. A., Gaiser, E. E., Zieman, J. C., Wachnicka, A. H., 2006: Spatial and temporal distributions of epiphytic diatoms growing on Thalassia testudinum Banks ex König: relationships to water quality. Hydrobiologia 569, 259-271.

Goma, J., Rimet, F., Cambra, J., Hoffmann, L., Ector, L., 2005: Diatom communities and water quality assessment in mountain rivers of the upper Segre basin (La Cerdanya, Oriental Pyrenees). Hydrobiologia 551, 209-225.

Hindák, F., Marvan, P., Komárek, J., Rosa, K., 1978: Sladkovodne riasy. Slovenske pedagogicke nakladatelstvo, Bratislava.

Hoffman, G., Werum, M., Lange-Bertalot H., 2011: Diatomeen im Süsswasser-Benthos Von Mitteleuropa: Bestimmungsflora Kieselalgen Für Die Ökologische Praxis : Über 700 der häufigsten Arten und ihre Ökologie. A.R.G. Gantner.

Hürlimann, J., Schanz, F., 1993: The effects of artificial ammonium enhancement on riverine periphytic diatom communities. Aquatic Sciences 55, 40-64.

IZAgirRe, O., ElosEgi, A., 2005: Environmental control of seasonal and inter-annual variations of periphytic biomass in a North Iberian stream. Annales de Limnologie - International Journal of Limnology 41, 35-46. 
JASPRICA, N., HAFNER, D., 2005: Taxonomic composition and seasonality of diatoms in three Dinaric karstic lakes in Croatia. Limnologica 35, 304-319.

Jasprica, N., Caric, M., Krsinic, F., Kapetanovic, T., Batistic, M., Nuire, J., 2012: Planktonic diatoms and their environment in the lower Neretva River estuary (Eastern Adriatic Sea, NE Mediterranean). Nova Hedwigia 141, 405-429.

Kelly, M. G., Gomez-Rodriguez, C., Kahlert, M., Almeida, S. F. P., Bennett, C., et al., 2012: Establishing expectations for pan-European diatom based ecological status assessments. Ecological Indicators 20, 177-186.

KIss, K. T., KleE, R., Ector, L., Ács, É., 2012: Centric diatoms of large rivers and tributaries in Hungary: morphology and biogeographic distribution. Acta Botanica Croatica 71, $1-53$.

Krivograd Klemenčič, A., Smolar-Žvanut, N., Istenič, D., Greissler-Bulc, T., 2010: Algal community patterns in Slovenian bogs along environmental gradients. Biologia 65, $422-437$.

Krivograd Klemenčič, A., Toman, M. J., 2010: Influence of environmental variables on benthic algal associations from selected extreme environments in Slovenia in relation to the species identification. Periodicum Biologorum 112, 179-191.

KomÁrek, J., Anagnostidis, K., 2002: Cyanoprokaryota. 2. Teil: Oscillatoriales. In: Büdel, B., Gartner, G., Krienitz, L, Schagerl, M. (eds.), Suswasserflora von Mitteleuropa, Band 19/2.. Elsevier, Spektrum akademischer Verlag, München.

Kosi, G., ŠišKo, M., Bricelu, M., Urbanič, G., Grbovič, J., Rotar, B., Stanič, K., 2006: Adaptation of Saprobic Index to the demands of Water Framework Directive (Directive 2000/60/EC) for the assessment of ecological state of the rivers in Slovenia using phytobenthos (in Slovenian).

Krammer, K., Lange-Bertalot, H., 1986-1991: Bacillariophyceae. Süßwasserflora von Mitteleuropa, 2 (1-4). Fischer, Stuttgart.

Lange, K., Liess, A., Piggott, J. J., Townsend, C. R., Matthaei, C. D., 2011: Light, nutrients and grazing interact to determine stream diatom community composition and functional group structure. Freshwater Biology 56, 264-78.

Martínez De Fabricius, A. L., Maidana, N., Gómez, N., Sabater, S. 2003: Distribution patterns of benthic diatoms in a Pampean river exposed to seasonal floods: the Cuarto River (Argentina). Biodiversity and Conservation 12, 2443-2454.

Monteiro, M. I. C., Ferreira, F. N., de Oliveira, N. M. M., Ávila, A. K., 2003: Simplified version of the sodium salicylate method for analysis of nitrate in drinking waters. Analytica Chimica Acta 477, 125-129.

Moss, B., 2010: Ecology of Freshwaters. Wiley-Blackwell, Chichester.

PAssy, S. I., 2007: Community analysis in stream biomonitoring: What we measure and what we don't. Environmental Monitoring and Assessment 127, 409-417.

PodAnI, J., 2001: SYN-TAX-2000. Computer programs for data analysis in ecology and systematics. Scientia Publishing, Budapest.

SoININEN, J., 2007: Environmental and spatial control of freshwater diatoms - a review. Diatom Research 22, 473-490.

Soltanpour-Gargari, A., Lodenius, M., Hinz, F., 2011: Epilithic diatoms (Bacillariophy- 
cae) from streams in Ramsar, Iran. Acta Botanica Croatica 70, 167-190.

TER BRAaK, C. J. F., Šmilauer, P., 2002: CANOCO release 4 reference manual and user's guide to Canoco for Windows: software for canonical community ordination. Microcomputer Power, Ithaca, New York.

TER BRAaK, C. J. F., Verdonschot, P. F. M., 1995: Canonical correspondence analysis and related multivariate methods in aquatic ecology. Aquatic Sciences 57, 255-289.

VÁrbíró, G., Borics, G., Csányi, B., Fehér, G., Grigorszky, I., Tihamér Kiss, K., Tóth, A., É. Ács, 2012: Improvement of the ecological water qualification system of rivers based on the first results of the Hungarian phytobenthos surveillance monitoring. Hydrobiologia $695,125-135$.

Velghe, K., Vermaire, J. C., Gregory-Eaves, I., 2012: Declines in littoral species richness across both spatial and temporal nutrient gradients: a palaeolimnological study of two taxonomic groups. Freshwater Biology 57, 2378-2389.

Virtanen, L. K., Köngäs, P., Aitto-Oja, S., Soininen, J., 2011: Is temporal occurrence of diatoms related to species traits, local abundance, and regional distribution? Journal of Phycology 47, 1445-1453.

VirTANen, L., SoInINEN, J., 2012: The roles of environment and space in shaping stream diatom communities. European Journal of Phycology 47, 160-168.

Xu, C., Xiangdong, Y., Xuhui, D., Enfeng, L., 2012: Influence of environmental and spatial factors on the distribution of surface sediment diatoms in Chaohu Lake, southeast China. Acta Botanica Croatica 71, 1-12. 